\title{
Ou não (1973), de Walter Franco: contracultura, experimentalismo e vanguarda na MPB
}

\author{
Sheyla Castro Diniz \\ Universidade de São Paulo (USP)
}

\begin{abstract}
Resumo
Músico atuante desde os anos 1960, Walter Franco surpreendeu o público e a crítica ao defender sua inusitada composição "Cabeça" no VII Festival Internacional da Canção da TV Globo, em 1972. Apesar das vaias que recebeu, o júri saiu em sua defesa por reconhecer a ousadia e a inovação da proposta num ambiente que prezava pelo lirismo e por formas musicais já padronizadas. Além das polêmicas que marcaram o VII FIC, este artigo analisa o primeiro álbum de Walter Franco, Ou não, lançado pela gravadora Continental em 1973. Busca, assim, discutir os aspectos contraculturais e experimentais presentes no disco bem como o seu caráter vanguardista não obstante a suposta inviabilidade de vanguardas emergirem no seio da indústria cultural.
\end{abstract}

Palavras-chave: Walter Franco; LP Ou não; contracultura; experimentalismo; vanguarda.

\section{Introdução}

Em 1972, Júlio Medaglia alertava no Jornal do Brasil sobre a "crise da MPB". Para ele, nada de relevante havia surgido na música popular brasileira depois de findado o movimento tropicalista em 1968. Apenas quatro músicos mereceram de sua parte algumas ressalvas: Chico Buarque, pela criatividade das letras, Caetano Veloso, pela teatralidade em palco, Gilberto Gil, pela técnica violonística, e Egberto Gismonti, pelo "trabalho sério". Exceto esses, as inovações dos cancionistas em meio à efervescência político-cultural que caracterizou a segunda metade dos anos 1960, impulsionadas de um modo ou de outro pelas novas demandas do mercado fonográfico e da indústria cultural como um todo, haviam categoricamente se esgotado. O único caminho para que a música popular recuperasse a ousadia e propusesse algo de realmente instigante seria apostar na "volta da polêmica", o que exigiria dos compositores estudo e pesquisa: "Essa história de que ninguém aprende samba na escola" - alusão ao samba "Feitio de oração", de Noel Rosa - "já atrasou muito a MPB" (MEDAGLIA, 1972, p. 5). 
A opinião um tanto elitista do maestro, arranjador e um dos mais notáveis apoiadores do tropicalismo, se inseria, até certo ponto, numa tradição de pensamento que se alastrava. Em 1977, por exemplo, Gilberto Vasconcellos faria referência aos "anos de chumbo" (19691974) como o berço de uma "cultura da depressão". A presença castradora da censura, internalizada na própria sintaxe da canção, teria favorecido a banalidade. Sob o signo da ameaça, e informada por uma contracultura que pouco se assemelhava ao "universo solar" tropicalista, essa "cultura da depressão" teria declarado espúria ou careta a esfera do político, procurando se manifestar através do discurso nonsense, irracional, místico e escapista (VASCONCELLOS, 1977, p. 64-72). Antes disso, o jornalista Zuenir Ventura já havia cunhado uma famosa expressão para distinguir a trivialidade que, em sua leitura, passou a dominar as artes do período. Em 1971, na revista Visão, argumentou que "o desaparecimento da temática polêmica e da controvérsia na cultura [...], a emergência de falsos valores estéticos, a hegemonia de uma cultura de massa buscando apenas o consumo fácil" seriam sintomas, dentre outros, do que chamou de "O vazio cultural" (VENTURA, 2000, p. 40-51).

Somado ao processo de consolidação do mercado de bens culturais sob o "milagre econômico" do governo Médici (1969-1974), o Ato Institucional n. 5 (Al-5), decretado em dezembro de 1968, foi, para muitos, um golpe quase que irreversível no conjunto da produção artística. Apesar das diferentes nuanças de análises, artistas, jornalistas e intelectuais constatavam que, encerrada a década de 1960, encerravam-se concomitantemente a arte considerada engajada e tributária do nacional-popular ${ }^{1}$ e as experiências formais com requintes de vanguarda. Seja como for, esses diagnósticos pessimistas não deixariam de se surpreender com algumas iniciativas artísticas inusitadas veiculadas nos meios de comunicação de massa da época. Dentre elas, a apresentação de Walter Franco no VII Festival Internacional da Canção (VII FIC) da TV Globo, em 1972. O compositor e intérprete da música "Cabeça", indo muito além do previsível num evento destinado ao grande público, enfrentava, segundo Gilberto Vasconcellos (1978, p. 28), "o problema da exaustão das formas".

Neste artigo ${ }^{2}$, discuto as polêmicas que marcaram o referido festival para, em seguida, analisar o primeiro álbum de Walter Franco, Ou não (1973), caracterizado por práticas experimentais e por referências contraculturais e vanguardistas. Por fim, e atendo-me à Música Popular Brasileira daquela época de intensas transformações políticas, econômicas e

\footnotetext{
${ }^{1}$ Em linhas gerais, o nacional-popular está ligado à construção da memória nacional através da valorização do folclore e da cultura popular. Embora orientasse setores à direita, esse ideário nutriu em suas várias nuanças a perspectiva engajada, nacionalista e/ou revolucionária de boa parte do pensamento de esquerda e da produção artística dos anos 1960. Para uma discussão a respeito, ver, por exemplo, Renato Ortiz (2006, p. 149-181; 2006b, esp. p. 68-78).

2 Dedico o artigo a Walter Franco (in memoriam), a quem tive a oportunidade de agradecer pessoalmente pelos ricos diálogos e reflexões que me confiou em mais de uma ocasião.
} 
socioculturais, trago algumas contribuições ao debate envolvendo a viabilidade de propostas vanguardistas emergirem na indústria cultural.

\section{“Cabeça" no VII FIC}

Estudante de arte dramática na Universidade de São Paulo e compositor de trilhas sonoras para peças de teatro, o paulistano Walter Franco (1945-2019) participou de todas as edições do Festival Universitário da TV Tupi nos anos 1960, tendo, na edição de 1968, a canção "Não se queima um sonho" defendida por ninguém menos que Geraldo Vandré, um dos principais ícones da "canção de protesto". Nunca gravada e desclassificada, não obstante a ovação ao intérprete, tal canção homenageava Che Guevara, recém-assassinado na Bolívia: "Seu sonho sem mortalha/ Cercado de solidão/ Eu trago bem guardado/ Na espera e no coração/ Vem, ó!/ Meu companheiro, Che/ Seu sonho quero Ihe dar" (FRANCO, 2016). "Não se queima um sonho" chamou a atenção de Rogério Duprat, o arranjador do álbummanifesto dos tropicalistas Tropicália ou Panis et circencis (1968). Chamou sua atenção, porém, de modo negativo, já que, na época, Duprat declarou ao jornal Folha da Tarde: "Se Guevara estivesse aqui não ia gostar nem um pouco. É preciso acabar com toda essa choradeira em torno do guerrilheiro, não é assim que se faz uma revolução!" (apud NUZZI, 2015, p. 152).

Filho do poeta e radialista Cid Franco - o primeiro vereador socialista da cidade de São Paulo, cujo mandato foi cassado logo após o golpe militar de 1964 -, Walter Franco herdou da família uma formação política de esquerda e o gosto pelas artes. Imerso na efervescência político-cultural que caracterizou o final da década de 1960, seu rol de interesses se ampliou para novos valores que, inicialmente impulsionados pelo tropicalismo, vinham no bojo das variadas práticas e experiências contraculturais que emergiam de maneira idiossincrática em solo brasileiro no pós-68 (ver, por ex., DUNN, 2016; FAVARETTO, 2019). Dentre essas práticas e experiências, a espiritualidade oriental, a meditação, o pensamento holístico amparado nos opostos complementares Yin-Yang e demais aspectos associados a sistemas de crenças e filosofias não ocidentais nutriram curiosidades e mudanças de mentalidade e comportamento de parcelas da juventude sob a racionalidade do Estado autoritário. $O$ experimentalismo nas artes se somou à guinada subjetiva de Walter Franco por volta de 1972, ano em que, no VII Festival Internacional da Canção da TV Globo (VII FIC), ele surpreenderia os jornalistas, o público e o júri ao incorporar o mesmo princípio, de Maiakovski, que fundamentara a crítica de Rogério Duprat: "Sem forma revolucionária não há arte revolucionária". 


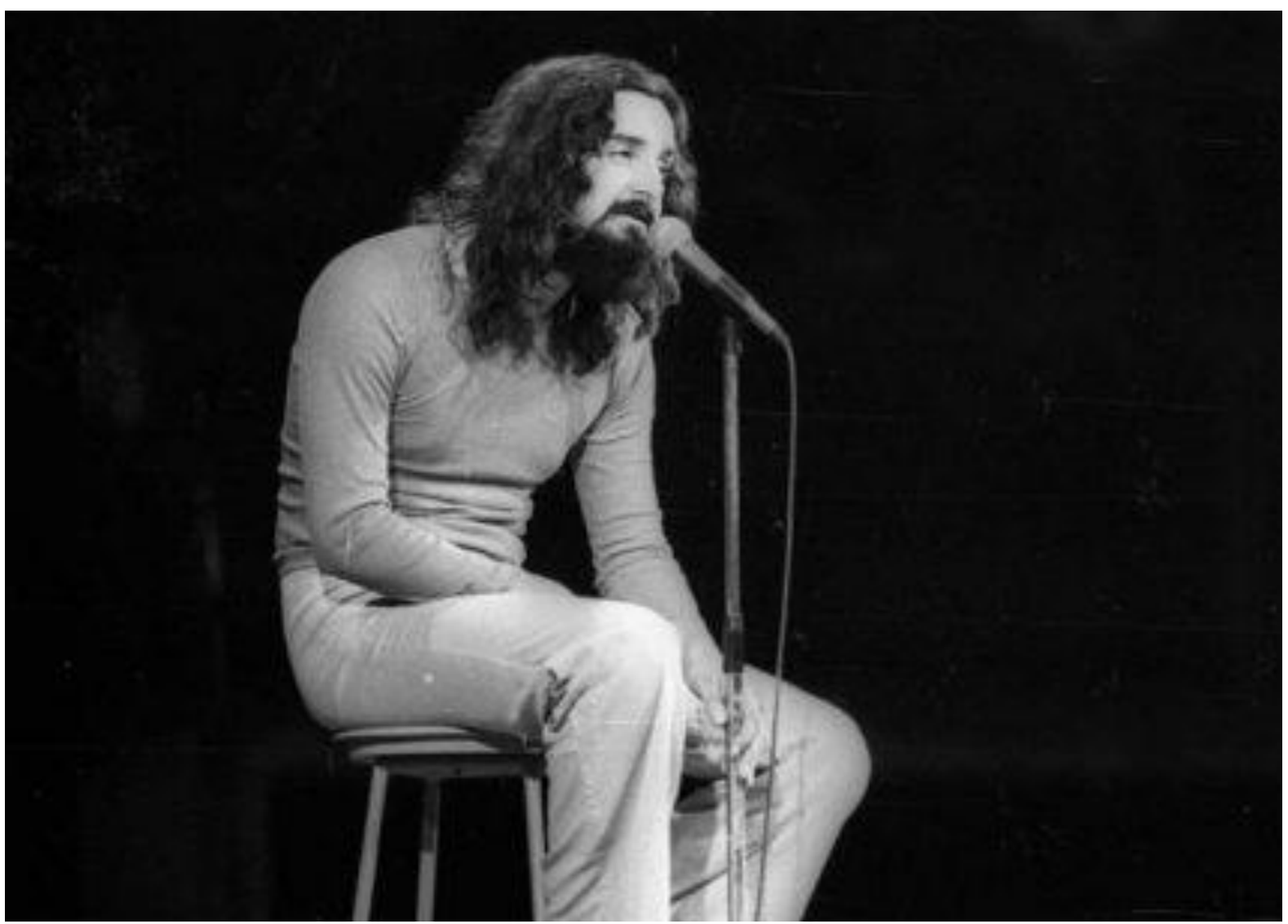

Figura 1 - Walter Franco, anos 1970 (fonte: Instituto Moreira Sales, 2019)

Em 1972, após promover dois festivais internacionais da canção (V FIC e VI FIC), um em 1970 e o outro em 1971, e ambos politicamente conturbados e pouco exitosos em termos de público, a Globo almejava restituir o prestígio que tais eventos haviam conquistado nos anos 1960. José Bonifácio de Oliveira Sobrinho (Boni) e Walter Clark, então diretores da emissora, convidaram um expert no assunto, Solano Ribeiro, para organizar e dirigir o VII FIC, sediado no Rio de Janeiro, no ginásio do Maracanãzinho, nos meses de setembro e outubro de 1972. Concebido com base no "Padrão Globo de qualidade", e exibido tanto no Brasil quanto no exterior, aquele foi o primeiro festival brasileiro a ser transmitido em TV em cores, aparelho aos poucos acessível à classe média do país. Solano Ribeiro se encarregou de selecionar os músicos concorrentes e de montar o corpo de jurados, do qual participaram, para citar alguns nomes, Nara Leão (escalada presidente), Rogério Duprat, o poeta Décio Pignatari, o empresário e produtor musical Guilherme Araújo e os jornalistas Sérgio Cabral, Walter Silva e Roberto Freire, também psiquiatra e fundador da Somaterapia ${ }^{3}$.

3 Processo terapêutico contemporâneo dos questionamentos suscitados pelas práticas libertárias e comportamentais da contracultura, a Somaterapia foi criada a partir de estudos de Wilhelm Reich e de premissas anarquistas, incluindo ainda técnicas de teatro e de capoeira angola. 
Poucos músicos já conhecidos e experientes se inscreveram no VII FIC: Hermeto Pascoal, a banda Mutantes e os parceiros Baden Powell e Paulo César Pinheiro. Dentre as revelações para além de Walter Franco estavam alguns dos nomes que alcançariam destaque na MPB: Alceu Valença, Fagner, Belchior e Ednardo, Renato Teixeira, Sirlan e Murilo Antunes, Sérgio Sampaio, Raul Seixas e a cantora Maria Alcina, responsável por interpretar, do já famoso Jorge Ben, a canção "Fio maravilha", vencedora da fase nacional cujo prêmio dividiu com "Diálogo", de Baden Powell e Paulo César Pinheiro - ou seja, as obras campeãs não levavam a autoria de nenhum dos novos músicos. Da apresentação de Walter Franco não há filmagens nem registros de áudio disponíveis". Sua estranha composição "Cabeça", como assim a adjetivaram alguns críticos, foi classificada para as etapas eliminatórias da fase nacional, o que desencadeou uma série de conflitos e um clima tenso envolvendo o público, os jurados, os diretores da TV Globo bem como a polícia militar que acompanhava de perto o evento.

\begin{abstract}
Sem instrumento, desarmado diante do microfone, o compositor Walter Franco falava pausadamente a letra de sua concorrente, "Cabeça" ("Que é que tem nessa cabeça, irmão? / Que é que tem nessa cabeça, ou não?'), enquanto as vaias aos poucos tomavam a grandiosa redoma do Maracanãzinho. Num certo momento, os movimentos calculados, quase hipnóticos de Franco, um ex-aluno de arte dramática, aparentavam reger a uníssona trilha sonora da plateia. E "Cabeça", uma letra sem melodia, recitada com fundo de voz e ruídos de sintetizador eletrônico gravados, receberia mais urros depois de classificada. Na reapresentação, Walter manteve-se mudo e estático no palco, ouvindo a irradiação da fita, e era um vitorioso quando ela terminou. O coro ritmado de insultos, só repetido nos campos de futebol, mostrava que ao menos os poucos mais 4.000 expectadores da primeira eliminatória (calculamse 3.000 na segunda), não tinham ficado indiferentes. $E$ isso num festival tão pouco emocionante já representava algo raro. (ARAÚJO, 1972, p. 83-84).
\end{abstract}

Incompatível com a fruição e a compreensão imediatas, "Cabeça" evidentemente não agradou ao público do festival. Reiterando a descrição acima, de Olívio Tavares de Araújo, o jornalista Júlio Hungria, no semanário O Pasquim, acrescentava que Walter Franco foi o único

[...] de todo o elenco do Festival Internacional a fazer alguma coisa de útil, a usar a máquina [o sistema, a TV, a indústria cultural] - ele apresentou um número que, bom ou mau, não interessa, produz efeitos, faz a plateia pensar (depois de vaiar): ele está ali, com aquela música concreta esquisita, espantosa, modificando, num trabalho de formiguinha que seja, os hábitos triviais de uma sociedade. (HUNGRIA, 1972, p. 17).

Hungria comparava ainda a apresentação de Walter Franco com a que o músico Jards Macalé havia realizado no IV FIC de 1969, ao concorrer com sua ruidosa canção "Gothan City", cuja letra, de José Carlos Capinan, fazia alusões ao recrudescimento do regime militar

\footnotetext{
${ }^{4}$ A gravadora Som Livre, da Rede Globo, lançou na época dois LPs do VII FIC: um com os maiores sucessos de público e o outro intitulado As 12 finalistas do VII Festival da Canção Popular (1972). "Cabeça" está registrada neste último, porém na voz do cantor mineiro Eustáquio Senna sob um arranjo menos experimental em relação à gravação do LP de Walter Franco, Ou não (1973).
} 
pós-edição do AI-5. Walter e Macalé, que, dentre outros, foram rotulados pela indústria fonográfica e pela imprensa da época com a alcunha de "músicos malditos", haja vista não corresponderem a determinados padrões estéticos nem ao gosto dominante, protagonizaram as maiores vaias até então registradas em festivais de música popular desde a provocação de Caetano Veloso com "É proibido proibir" no III FIC, de $1968^{5}$. Como que retomando a provocação um ano depois, Jards Macalé e banda (Os Brazões) geraram uma atmosfera caótica e musicalmente agressiva no IV FIC ${ }^{6}$. Já na sétima edição do evento, Walter Franco adotou outra tática ante a rejeição da plateia, que, contudo, entendeu seu silêncio e sua postura pacífica em palco como "réplica desrespeitosa" (VARGAS, 2010, p. 205) ${ }^{7}$.

Em entrevista à jornalista Ana Maria Bahiana, o músico confirmou que aquele foi um momento "de grande violência. Eu sabia que estava confundindo as pessoas lançando o sim e o não numa contagem muito rápida. As pessoas reagiam jogando de volta uma carga negativa fortíssima, mesmo quando eu repetia uma palavra positiva como 'irmão'" (apud BAHIANA, 2006, p. 274-275). Apresentando uma "não-canção" num festival da canção, Walter Franco contrariou o previsível, reverberando até certo ponto o lema de José Celso Martinez Corrêa, do Teatro Oficina: "Todo consentimento entre palco e plateia é um erro ideológico e estético" (apud SCHWARZ, 1978, p. 85). E ainda que remetesse à solidariedade cristã tão abundante na MPB dos anos 1960, a palavra "irmão" ("Que é que tem nessa cabeça, irmão?") não surtiu efeito ou empatia semelhantes. Num happening à la John Cage em 4'33"' (1952) - obra conceitual em que o pianista, frustrando as expectativas numa sala de concerto, não executa nota alguma -, Walter integrou a agitação e as vaias à própria forma de "Cabeça".

Antes da última fase nacional do VII FIC, agentes da censura exigiram que a TV Globo demitisse do júri Nara Leão, sob o pretexto de que a cantora havia concedido uma "entrevista subversiva" ao Jornal do Brasil. Solano Ribeiro destituiu todo o corpo de jurados, com a intenção, segundo ele, de provocar uma "situação política" (ver MELLO, 2003, p. 421-424; BOZZO JUNIOR, 2000). Para Décio Pignatari e Rogério Duprat, essa atitude controversa tinha a ver com "Cabeça", que, se dependesse deles e da maioria dos jurados, venceria o festival (ver Bechara; Serpa, 2000). De fato, a TV Globo estava mais interessada em Maria Alcina. Mulher de timbre marcante, tessitura vocal grave, portando roupas coloridas e abusando de trejeitos extravagantes em sua performance, Alcina contagiou a plateia ao defender a canção de Jorge Ben, que, em pleno Maracanãzinho, homenageava o atacante

\footnotetext{
5 Trechos da participação de Caetano Veloso (acompanhado da banda Os Mutantes) e de seu discurso provocador no III FIC (1968) podem ser conferidos no documentário Tropicália (MACHADO, 2012).

6 Para ouvir o registro de "Gothan City" no IV FIC, em cujo refrão Macalé alertava "Cuidado! Há um morcego na porta principall Cuidado! Há um abismo na porta principal", conferir: https://www.youtube.com/watch?v=epz1isKVpTQ. Acesso: 04 fev. 2021.

${ }^{7}$ A título de curiosidade, no documentário Walter Franco Muito tudo, Jards Macalé certifica a interlocução daquelas propostas iconoclastas ao cantar "Gothan City" modificando o refrão: "Cuidado! Há um Walter na porta principal!/ Cuidado! Há um Franco na porta principal!” (ver BECHARA; SERPA, 2000).
} 
do Flamengo João Batista de Sales, mais conhecido como Fio Maravilha. Substituído por uma delegação estrangeira, o júri demitido redigiu um manifesto no qual criticava a Globo e a censura, indicando ainda a sua decisão a favor de Walter Franco. Ao subir ao palco e tomar o microfone para ler o manifesto, Roberto Freire - ex-militante da organização política Ação Popular, e, portanto, visado pelos militares - foi arrastado por seguranças da TV Globo a uma sala atrás do palco, sofrendo ali uma brutal agressão policial (ver MELLO, 2003, p. 427; 429; FREIRE, 2002, p. 266-267).

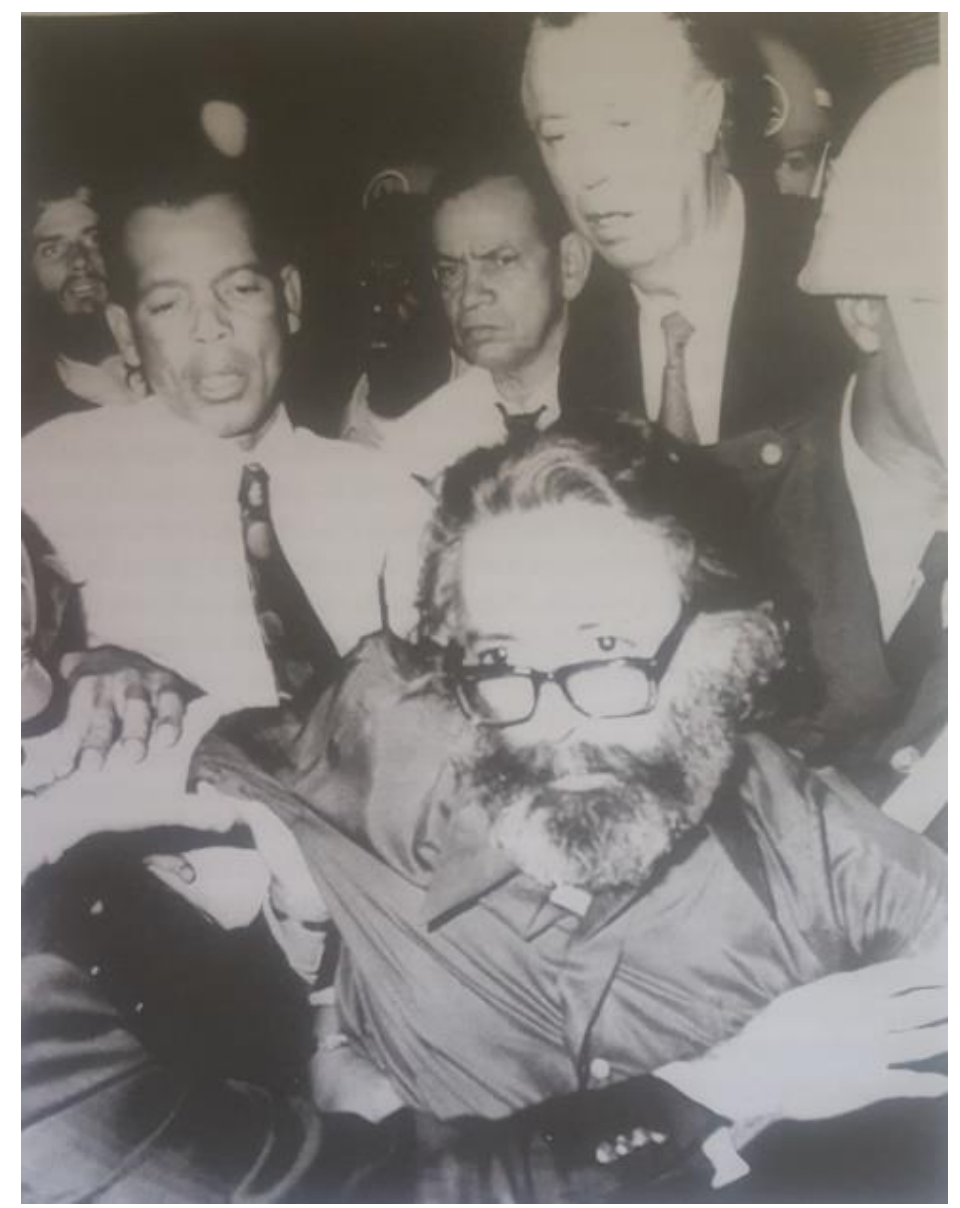

Figura 2 - Roberto Freire sendo arrastado do palco do VII FIC (fonte: MELLO, 2003, p. 429)

Apesar do "Padrão Globo de qualidade", o VII FIC teve um índice de audiência bem aquém do esperado, acarretando algum prejuízo à Rede Globo e sendo também ineficaz quanto à pretensão do regime militar de, através dos festivais, exportar uma "boa imagem do Brasil" ao exterior. Diretor do evento, Solano Ribeiro observou que a plateia, de apenas quatro mil pessoas nas eliminatórias, compareceu ao Maracanãzinho menos para apreciar as canções que para desfrutar do espetáculo televisivo (apud SCOVILLE, 2008, p. 63). Embora ainda funcionassem como ambientes de amostras de novos talentos junto às gravadoras e ao público, os festivais naquele formato competitivo esmoreciam sob a intervenção da censura 
e a organização sistêmica da indústria cultural. Tanto é que o sétimo e último FIC - não obstante o "Festival Abertura" realizado pela Globo em 1975, do qual Walter Franco também participou - é considerado o derradeiro da "era dos festivais".
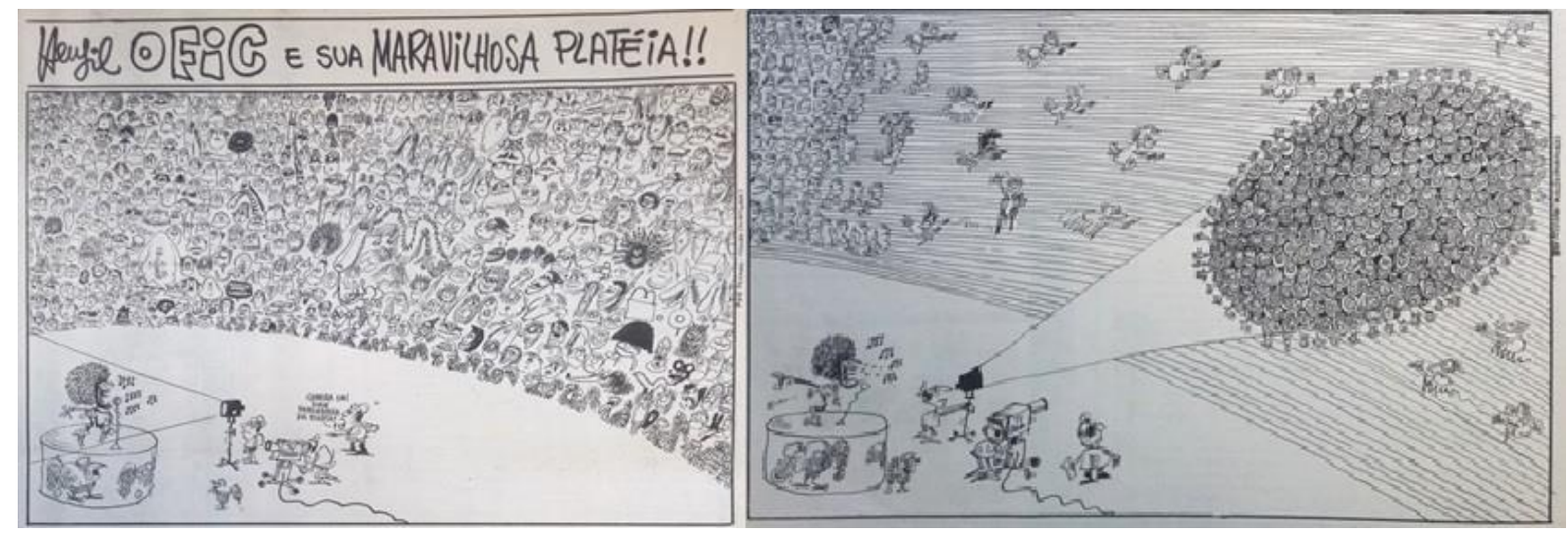

Figura 3 - O FIC e sua maravilhosa plateia!, cartum de Henfil no jornal O pasquim, ironizando a plateia do VII FIC (fonte: HENFIL, 1972).

Numa entrevista concedida ao Pasquim em 1974, André Midani relatava que, no ano anterior, a Philips/Phonogram havia vendido mais discos que toda a indústria fonográfica brasileira em 1968. O diretor da multinacional no Brasil insistia na distinção entre "músicos de catálogo" e "músicos de marketing". Ou seja, produzindo discos mais elaborados, os primeiros garantiriam o status quo da Phonogram junto à crítica e ao público intelectualizado de classe média. Já os segundos, menos onerosos e com finalidade comercial, contemplariam as camadas mais populares. Com seu cast e seus segmentos de consumo assegurados, à Major era preferível manter no elenco Odair José, o "cantor das empregadas" - rótulo pejorativo que pretendia designar o recorte de classe das fãs -, do que investir num novo grupo de estrondoso sucesso como os Secos \& Molhados. Era mais vantajoso apostar num trabalho experimental do já consagrado Caetano Veloso, o LP Araçá azul (1973), cujas vendas fracassaram, do que contratar outro tropicalista cada vez mais inovador e esteticamente radical como Tom Zé - vide o seu LP Todos os olhos (1973) - ou então um principiante no mercado fonográfico como Walter Franco ${ }^{8}$.

Muito do que não convinha às Majors naquele início dos anos 1970, momento em que a indústria fonográfica alcançava, portanto, um estágio de consolidação bem mais integrado, racional e capitalizado, seria acolhido por gravadoras nacionais de pequeno ou médio porte. É a convite do jornalista Walter Silva, um dos jurados do VII FIC e diretor artístico da gravadora

\footnotetext{
${ }^{8}$ Essas informações se baseiam na entrevista de André Midani (1974) ao Pasquim. Para duas análises minuciosas do funcionamento da indústria fonográfica brasileira dos anos 1970, ver Dias (2000) e Morelli (2009).
} 
Continental, que Walter Franco lança, em 1972, dois compactos simples ${ }^{9}$, e, em 1973, o seu primeiro LP, intitulado Ou não.

\section{Ou não}

Para conceber o seu álbum de estreia, Walter Franco contou com Décio Pignatari na coordenação gráfica e com Rogério Duprat na produção musical. O LP Ou não foi gravado no estúdio paulistano Eldorado, o mesmo no qual Caetano Veloso gravava, pela Phonogram, o LP Araçá azul (1973), cujos arranjos são assinados por Duprat. Sendo Walter Franco um "póstropicalista" - termo veiculado pela crítica para abranger uma porção de iniciativas musicais que desponta no pós-68 -, é evidente que ele não passou incólume pelo movimento que, no fim dos anos 1960, propôs revolucionar a MPB. Ícone tropicalista por excelência, Caetano, contudo, não passaria incólume pela "Cabeça" de Walter Franco. Ora, em seus respectivos discos, gravados na mesma época e estúdio e lançados no mesmo mês de fevereiro de 1973, notam-se influências mútuas e uma mesma radicalidade experimental a tensionar o mainstream $^{10}$.

Para além da importante presença de Rogério Duprat em ambos os discos, isso se deve, em boa medida, ao fato de o Eldorado ser o único estúdio brasileiro a dispor, no início dos anos 1970, de uma mesa de som com 16 canais. Manejada pelo engenheiro de som Marcus Vinicius - outro tachado "maldito" após emplacar (e empacar) seu primeiro LP'11 -, o equipamento, se comparado com mesas de dois ou quatro canais, aumentava exponencialmente a possibilidade de distribuição das vozes, oferecendo, assim, novos recursos para a equalização e a mixagem do som estéreo.

Walter Franco transportou para o seu disco muito da experiência que adquiriu no teatro. Como quem assume personagens ao interpretar as composições, todas elas de sua autoria, ele recorre a entonações e comportamentos vocais dos mais variados. Em que pese o caráter minimalista, seja na instrumentação seja nas letras das canções, o disco apresenta texturas sonoras densas e, como na faixa de abertura, um tratamento estético agressivo. Com apenas dois violões, baixo e percussões, "Mixturação" é uma canção de versos tão curiosos e sugestivos quanto o título do LP. Seria uma crise diante do imponderável? Uma desilusão amorosa que se quer superar? O impasse do artista naquele período de ditadura? Ou seria um parto doloroso e difícil? Em relato a Ayrton Mugnaini Jr., Walter afirmou ter substituído a

\footnotetext{
${ }^{9}$ Num desses compactos constam as canções "Por um triz" e "Me deixe mudo". Já no outro, ocupando os lados A e B, está "Cabeça", que, assim como "Me deixe mudo", possui arranjo diferente do que seria registrado no LP Ou não.

10 Para uma análise do LP Araçá azul, conferir Dietrich, 2003.

11 LP Dédalus, lançado por Marcus Vinicius, em 1974, pela gravadora Continental.
} 
palavra feto por afeto para que a letra não fosse novamente vetada pela censura (apud Mugnaini Jr., 2013, p. 395).

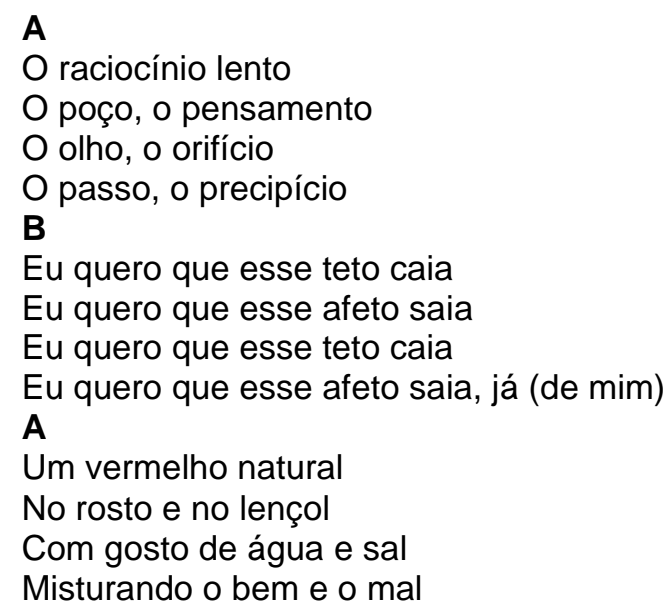

Opressões em vários níveis levaram o músico a se interessar pela Terapia primal, com a qual provavelmente tomou contato em laboratórios experimentais de teatro. Esta que é considerada uma terapia de choque foi inventada nos anos 1960 por Arthur Janov, psicólogo e psicanalista estadunidense que chegou a atender personalidades como o casal John Lennon e Yoko Ono. Álbum que inaugura a carreira de Lennon após a dissolução dos Beatles, John Lennon/Plastic Ono Band (1971) seria uma espécie de resultado desse processo terapêutico. O resgate de traumas retidos no subconsciente, incluindo o trauma do parto, quando se é "expulso" do ventre materno, reconectaria o paciente aos primeiros anos de vida, conduzindo-o aos poucos à catarse de um "grito primal". Escancarado anos mais tarde por Walter Franco em sua canção "Canalha", do LP Vela aberta (1979), tal grito já estava anunciado em "Mixturação". Na Seção B, o canto esganiçado dá a medida da violência, da dor e do sufoco de algo entranhado sem acabar de nascer. Todavia, esse "(a)feto" truncado, reforçado pelas alusões ao sangue ("vermelho natural”) e ao pranto (“Água e sal”, que é título, inclusive, da faixa seguinte), não deixa de ser a criação tolhida que, em tempos de cerceamento da liberdade de expressão, deseja a todo custo ser lançada para fora ${ }^{12}$.

Noutra evidente referência à censura, mas, antes disso, uma canção intimamente relacionada à sua prática meditativa e aos ensinamentos do taoísmo (STESSUK, 2008, p. 710), Walter Franco brinca com as palavras em "Me deixe mudo". Com intervalos de silêncio, ele as pronuncia pausadamente sílaba-a-sílaba sobre um ostinato ao violão, que, a princípio, não passa de um pizzicato aqui e outro acolá. Sob uma estrutura ternária, minimalista e

\footnotetext{
${ }^{12}$ Em entrevista a Charles Gavin, Walter Franco comenta de passagem sobre a Terapia primal. Referindo-se aos seus LPs Ou não (1973) e Revolver (1975), diz que "esses dois discos sintetizam isso, é a linguagem do autoconhecimento. É uma coisa assim..., até o grito primal. A busca da terapia através do grito, de você botar tudo pra fora. De você ao mesmo tempo recuperar o equilíbrio" (apud GAVIN, 2014).
} 
espiralar, tal qual um mantra, letra e melodia se revelam pouco a pouco num jogo de perguntas e respostas:
Não me pergunte
Não me responda
Não me procure
E não se esconda
Não diga nada
Saiba de tudo
Fique calada
Me deixe mudo
Seja no canto
Seja no centro
Fique por fora
Fique por dentro
Seja o avesso
Seja a metade
Se for começo
Fique à vontade
Não me pergunte
Não me responda
Não me procure
$E$ não se esconda
Não diga nada
Saiba de tudo
Fique calada
Me deixe mudo...

Um dos músicos mais vigiados pela censura da época, Chico Buarque gravou "Me deixe mudo" em seu LP Sinal fechado (Phonogram, 1974). Mas foi na voz e arranjo de Walter Franco que o poeta Augusto de Campos detectou o maior registro de silêncio até então efetuado na música popular brasileira, porém "um silêncio que fala, e não uma pausa comum" (apud BECHARA; SERPA, 2000). Sem se furtar, entretanto, de abordagens mais convencionais e comerciais naquele período, Walter é autor do tema de abertura da novela Hospital, exibida pela TV Tupi em $1971^{13}$.

Quem olhar pro fundo do poço

Quem olhar pro fundo do poço

Vai ter

Quem se olhar dos pés ao pescoço

Quem se olhar dos pés à cabeça

Vai ver

Que tudo é tão simples

Que tudo é tão claro

Tão claro, vai ver

Quem passar por cima do muro

Quem passar por cima do muro

Vai ter

Quem passar por cima do mundo

Quem passar por cima do mundo

${ }^{13} \mathrm{O}$ "Tema do hospital" foi gravado por Walter em compacto simples, lançado pela Philips/Phonogram em 1971. Para ver a abertura da novela Hospital, consultar: https://www.youtube.com/watch?v=BPs8O3HigoA. Acesso: 10 fev. 2021. 


\section{Vai ver \\ Que tudo é profundo \\ Que tudo é tão simples \\ Tão simples, vai ver...}

Dois anos depois, sob outra roupagem no LP Ou não, o "Tema do hospital" passa a se chamar "No fundo do poço". Repetindo insistentemente algumas palavras, às quais adiciona ecos e ruídos vocais, Walter, com o canto lento e enfático, converte uma balada singela de dois acordes numa canção experimental de arranjo soturno. A letra que antes soava leve, despretensiosa e até infantil é conduzida para a contemplação do vazio. Nos ritmos irregulares das percussões, nos solos do banjo que mais parece um sitar e nos pedais contínuos e esparsos do violão e do violoncelo, à semelhança do que faz uma tambura, são tecidas relações idiomáticas com a música indiana. Saltam aos olhos, mais uma vez, John Lennon e mais precisamente os Beatles como bússolas latentes a direcionar esse primeiro álbum de Walter, já que a inserção de instrumentos indianos e do universo místico oriental na música popular contracultural e/ou herdeira das vanguardas deve-se, em boa medida, ao pioneirismo da banda inglesa ${ }^{14}$. Dialogando com os Beatles, e também com os tropicalistas, Walter acessa valores e experiências da contracultura via questionamento da racionalidade ocidental.

Faixa mais cênica do LP Ou não, "Flexa" simula uma situação de perseguição e violência. A intepretação tragicômica picota canto e letra por meio de silêncios, ruídos e onomatopeias. Na harmonia econômica do violão é possível antever a construção de uma intertextualidade com a canção "Oriente", de Gilberto Gil, confirmada em seguida pela citação do verso ambíguo "Se oriente, rapaz...". Ao mencioná-lo, Walter Franco sugere, tal como Gil, tanto a necessidade objetiva de "orientar-se" em meio às adversidades quanto a busca subjetiva por equilíbrio na sabedoria oriental ${ }^{15}$. Aliás, pode ser que Walter tenha vislumbrado o título de seu álbum noutros versos de Gil para "Cultura e civilização" ("A cultura, a civilização/ Elas que se danem/ Ou não"), considerando ainda que uma composição como "Objeto semiidentificado", parceria de Gil com Rogério Duarte e Rogério Duprat, apresenta uma concepção experimental até certo ponto parecida com a da música "Cabeça"16.

Um constructo em que as vozes se sobrepõem e se atravessam distribuídas entre os canais, "Cabeça", tal qual registrada no LP Ou não, dispensa melodia e harmonia. Tampouco há nela métrica definida ou instrumentação, embora a mesa de som, assim como a voz, seja aqui um instrumento. Eis a letra tal qual foi idealizada:

\footnotetext{
${ }^{14}$ O sitar aparece, por exemplo, na canção de John Lennon e Paul McCartney Norwegian Wood (This bird has flown), do LP Rubber Soul (1965). E a tambura na canção de George Harrison Within you without you, do LP Sgt. Pepper's Lonely Hearts Club Band (1967).

15 "Se oriente, rapaz..." é verso da canção de Gillberto Gil Oriente, gravada em seu LP Expresso 2222 (1972). Para uma análise da canção, ver Diniz (2015).

${ }^{16}$ Cultura e civilização (Gilberto Gil) e Objeto semi-identificado (Gilberto Gil, Rogério Duarte e Rogério Duprat) estão gravadas no LP Gilberto Gil (1969).
} 
Que é que tem nessa cabeça irmão

Que é que tem nessa cabeça ou não

Que é que tem nessa cabeça saiba irmão

Que é que tem nessa cabeça saiba ou não

Que é que tem nessa cabeça saiba que ela pode irmão

Que é que tem nessa cabeça saiba que ela pode ou não

Que é que tem nessa cabeça saiba que ela pode explodir irmão

Que é que tem nessa cabeça saiba que ela pode explodir ou não

$\mathrm{Na}$ gravação do álbum, essa letra desobedece qualquer linearidade de exposição, embora possamos ouvir com nitidez uma frase-guia ("Essa cabeça saiba que pode explodir ou não"). Transcrita novamente abaixo, em destaques coloridos para facilitar a visualização, note-se que há uma correspondência intercalada e incremental entre os complementos adicionados à indagação constantemente repetida, resultando numa estrutura poética minimalista, porém convidativa à variação.

\author{
Que é que tem nessa cabeça irmão \\ Que é que tem nessa cabeça ou não \\ Que é que tem nessa cabeça saiba irmão \\ Que é que tem nessa cabeça saiba ou não \\ Que é que tem nessa cabeça saiba que ela pode irmão \\ Que é que tem nessa cabeça saiba que ela pode ou não \\ Que é que tem nessa cabeça saiba que ela pode explodir irmão \\ Que é que tem nessa cabeça saiba que ela pode explodir ou não
}

$\mathrm{Na}$ gravação, portanto, à técnica dadaísta de recortes e recombinações variadas juntam-se sons guturais, gemidos, palavras aleatórias, menções en passant de outras faixas do LP Ou não, ecos e silêncios, mas silêncios que equivalem ao ruído de baixa frequência emitido pela fita magnética, tecnologia indispensável, na época, à gravação estereofônica. Além disso, há uma dinâmica dialógica mesmo quando a polifonia vocal culmina em uma massa sonora, como se cada voz entrelaçada projetasse um estado psíquico, indo do alheamento ao desespero e da lucidez ao nonsense e ininteligível. "Quê é que tem" ora interroga e ora insinua desdém. Já "Ou não", ao colocar em dúvida a afirmação, é também uma interjeição a alertar para a iminência da "explosão da cabeça". Da confusão e loucura inegavelmente tematizadas no fonograma podem-se cogitar igualmente violência e medo da morte como possibilidades de significação. Seja como for, no desfecho dos quase cinco minutos de música, a realidade normativa interpela o vozerio onírico: "Que dia é hoje? Que dia é hoje? 19 de dezembro de 1972. Que horas são? Que horas são? Eu não tenho relógio. Onze e meia, onze e meia e vinte e seis", diálogo que antecede um suspiro de alívio.

Partindo da ideia de "linguagem da fresta", empregada por Gilberto Vasconcellos (1977) para se referir às metáforas, alegorias e outras artimanhas do compositor brasileiro visando a driblar a censura, Roberto Bozzetti propôs uma tipologia binária (sem ignorar intersecções) para as canções do pós-68. De um lado estariam as canções de confronto, que, marcadas pela pletora do discurso, "serviram para desnudar a violência e o arbítrio do tempo, mas seu 
efeito mais imediato foi silenciar os cancionistas" e prejudicar, na acepção do autor, a indústria fonográfica. De outro estariam as canções de esgar, caracterizadas pelo influxo da contracultura, pela subjetividade e pelo que denominou de rarefação do discurso. Com textos enigmáticos e gritos no canto, estas teriam sido "de forma geral testemunhas do péssimo estado de coisas para a prática dos cancionistas" (BOZZETTI, 2007, p. 138-141).

Por mais que o contexto propriamente político estivesse impregnado na própria estrutura e sintaxe das canções, conforme argumentou Vasconcellos (1997), tipologias como esta tendem a sugerir elos muito simétricos entre o experimentalismo (geralmente encontrado naquelas "canções de esgar"), a censura e a repressão, como se o primeiro fosse consequência direta do recrudescimento do regime. É relegado a um segundo plano o importante papel de uma revolução tecnológica sem precedentes pela qual passava o Brasil do "milagre econômico" (1969-1973).

Duas condições são essenciais ao experimentalismo de acordo com Umberto Eco: presença de novos materiais, frutos de pesquisa científica, e mudança de método, que implica negar ou subverter aspectos-chave de uma tradição (ECO, 2016, p. 224-229). A música "Cabeça", no caso, ou "antimúsica" - conforme o compositor a definiu em sintonia com a antiarte situada aproximadamente no mesmo período (apud MÚSICA BRASILEIRA, 1973) -, rompia com formas e parâmetros cancionais pré-estabelecidos. Isenta do que é elementar à canção, isto é, a melodia, ela prioriza o fenômeno sonoro em detrimento da altura das notas, exemplificando, assim, propostas defendidas por Rogério Duprat, Júlio Medaglia, Damiano Cozzella, Gilberto Mendes, dentre outros, no "Manifesto da nova música brasileira”, publicado em 1963 na revista de arte de vanguarda Invenção, criada e coordenada, na época, por Décio Pignatari. "Cabeça" remetia consequentemente à musique concrète de Pierre Schaeffer e aos silêncios, ruídos e "princípios zen da não previsibilidade" explorados em obras e concertos de John Cage (COHEN, 2002, p. 43), embora Walter Franco alegasse ser outra a fonte de suas ideias: "E eles [os poetas concretistas Décio Pignatari, Haroldo e Augusto de Campos] me perguntaram: 'Como você chegou a essas soluções? Você ouviu muito John Cage?'. Eu não ouvi nada! Cheguei por outros caminhos, os caminhos da intuição" (apud GAVIN, 2014). Ao trabalhar com o vasto potencial semântico, sonoro e visual da palavra, conferindo às suas criações musicais um caráter substancialmente isofórmico, Walter, além do mais, foi um dos compositores e performances que melhor reatualizou o projeto verbivocovisual da poesia concreta. 


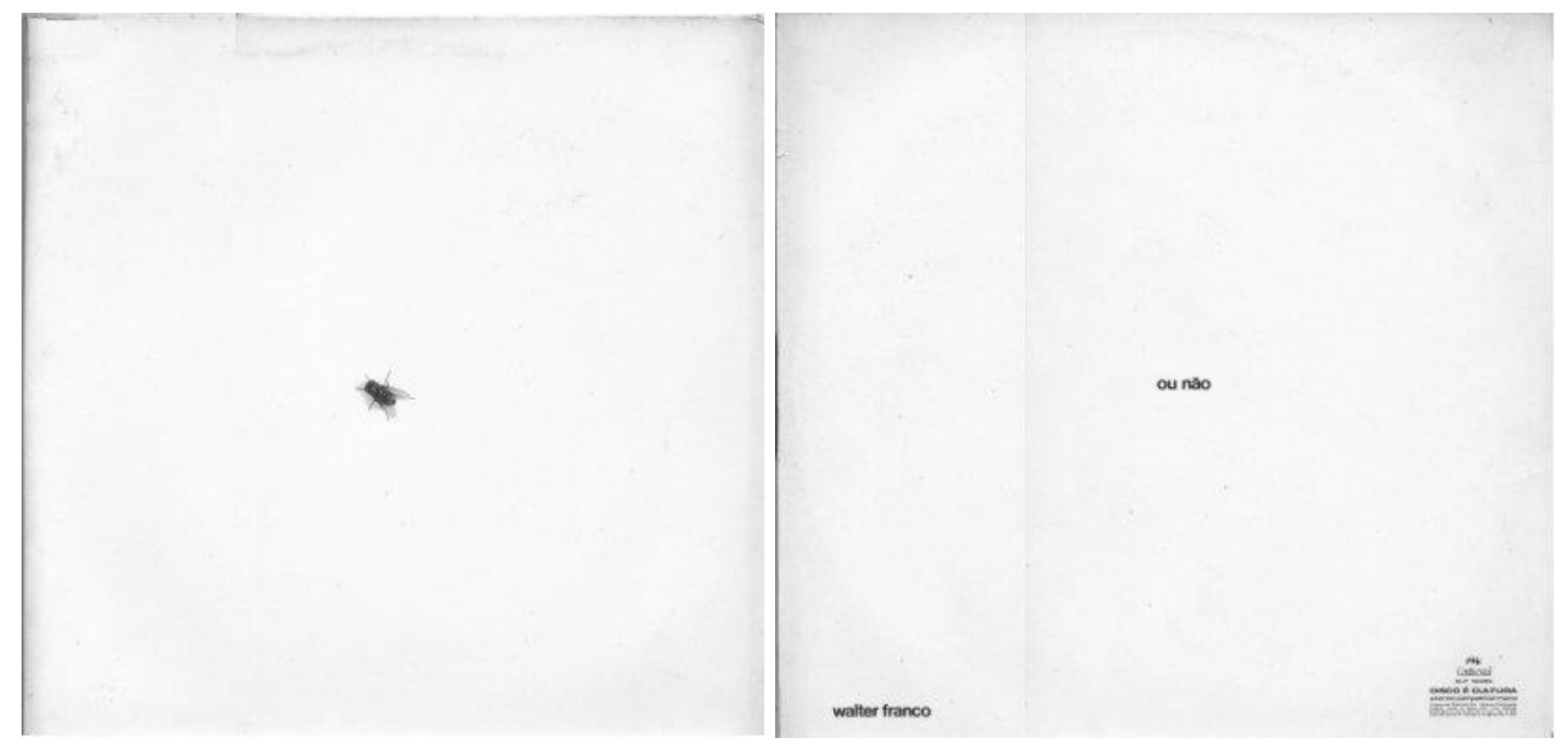

Figura 4 - Capa e contracapa do LP de Walter Franco Ou não, Continental, 1973; o projeto gráfico do álbum é assinado por Décio Pignatari (fonte: arquivo pessoal)

Ao invés de seu rosto e seu nome, Walter Franco optou por exibir uma mosca na capa do álbum. Reproduzida em tamanho real sob o fundo branco, a foto do inseto foi tirada, segundo o músico, no lixão da cidade de São Paulo (apud MUGNAINI JR, 2013, p. 397). Coincidência ou não, naquele ano de 1973 estourou nas paradas de sucesso a canção de Raul Seixas "Mosca na sopa" (LP Krig-Há Bandolo), que, entretanto, soava bem menos incômoda aos ouvidos do grande público do que o "disco da mosca" de Walter, que, quando lançado, não ultrapassou a cifra irrisória de umas duas centenas de cópias vendidas (FRANCO, 2016). No encarte da primeira tiragem do álbum havia um envelope; e, dentro dele, um texto extraído de uma apócrifa Enciclopédia Chinesa, intitulado "Empório celestial de conhecimentos benévolos":

Os animais se dividem em:

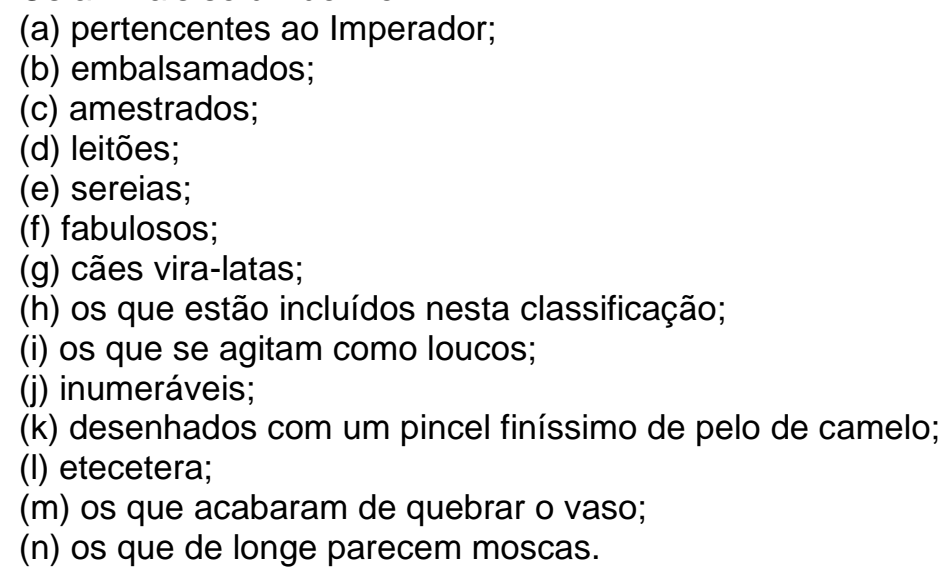


Ordenada conforme o sistema abecedário, mas sem qualquer critério lógico, essa classificação dos animais do universo é mencionada pelo escritor argentino Jorge Luís Borges no ensaio "O idioma analítico de John Wilkins" (1952). Filósofo inglês do século XVII, Wilkins forjou um sistema de medição e um esquema linguístico de pretensões universais, negligenciando obviamente que palavras e coisas assumem um complexo enredo de representações e significados nos mais diferentes contextos. Seu esquema engenhoso, porém especulativo, fez com que Borges o equiparasse à catalogação dos animais contida naquela Enciclopédia Chinesa, concluindo que, "notoriamente, não há classificação do universo que não seja arbitrária e conjectural. A razão é muito simples: não sabemos o que é o universo" (BORGES, 2007, p. 124).

Não só o texto chinês, mas também "O idioma analítico..." e quem sabe o livro As palavras e as coisas, de Michel Foucault ([1966] 1999), escrito a partir da leitura do ensaio de Borges, podem ter inspirado Walter Franco e Décio Pignatari a elaborarem o projeto gráfico do álbum. De um modo ou de outro, embalagem e encarte reforçam a proposta conceitual: palavras que, articuladas como signos sonoros e visuais, geram múltiplos sentidos. Enviesado pela imprensa, Ou não acabou se tornando um bordão atribuído a Caetano Veloso, não raras vezes acusado de se deixar cair em relativismos e contradições em sua condição de persona pública formadora de opinião. Contudo, ao nomear o disco, cujo título na contracapa faz um contraponto às ideias de incômodo e sujeira suscitadas pela mosca sobre o fundo clean, Walter Franco, profundo admirador do Livro do caminho e da virtude, o Tao te Ching (STESSUK, 2008, p. 7), reafirmava, em realidade, suas reservas quanto ao pensamento cartesiano ocidental.

Ademais de sintetizar o silêncio e o ruído que caracterizam as faixas gravadas no LP, a embalagem minimalista vai ao encontro do álbum The Beatles, ou Álbum branco (1968). Walter transparecerá seu apreço declarado pela banda no trabalho seguinte, Revolver(1975), disco que, marcado pela presença mais enfática do rock, mostra-se um pouco mais palatável comercialmente, mas sem que nele se perca a linguagem experimental. John Lennon é homenageado na capa: o terno branco de Walter, seus cabelos compridos, as mãos nos bolsos e a travessia de uma rua evocam a figura do ídolo na capa de Abbey Road (1969). Já o título, em referência e reverência indubitáveis a outro álbum dos Beatles, Revolver (1966), cria uma paronomásia. Pois, o que em inglês é o substantivo revólver, em português é revolver, verbo com uma lista ampla de sinônimos, como, por exemplo, "revirar", "desorganizar" e "redefinir". 


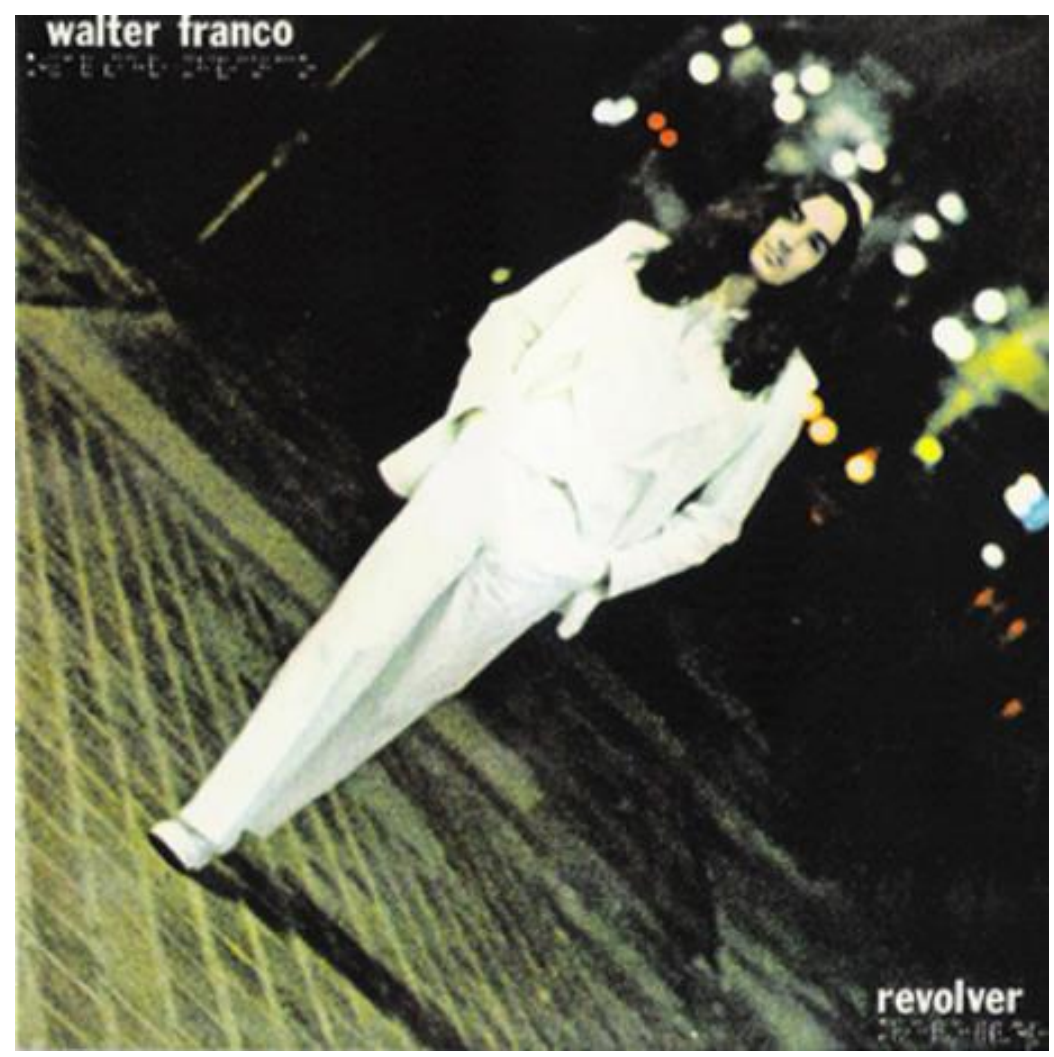

Figura 5 - Capa do LP de Walter Franco Revolver, Continental, 1975 (fonte: arquivo pessoal)

Em 1975, no Brasil, os grupos clandestinos de luta armada já haviam sido praticamente aniquilados pelo regime militar; a sociedade civil retomava o ânimo em mobilizações cada vez mais confiantes pela via democrática e boa parte dos valores, práticas e experiências da contracultura se diluía no mercado de bens culturais em plena consolidação. Os chamados "anos de chumbo" (1969-74) demandavam, portanto, um balanço. Tropicalista e arauto da contracultura, Gilberto Gil fez o seu no LP Refazenda (1975) - Gil que, parafraseando John Lennon na canção "God", já havia anunciado que "O sonho acabou"17. Zen e pacifista, porém não menos agressivo em matéria de forma e estética, Walter Franco compartilhava desse espírito dos tempos, propondo, com seu Revolver, uma "reviravolta" à procura de autoconhecimento, para, então, "redefinir" novos caminhos, fossem musicais, pessoais ou coletivos.

\section{Considerações finais: notas sobre um debate}

Em estudos sobre a produção artístico-intelectual brasileira do século XX, o período de 1920 a 1970 é geralmente apontado como expressão de um ciclo vanguardista ou modernista, impulsionado em larga medida pela Semana de Arte Moderna de 22 e pelos projetos de Mário

\footnotetext{
${ }^{17}$ A canção "God", na qual John Lennon afirma "The dream is over", está gravada no LP John Lennon/Plastic Ono Band (1971). Refletindo sobre o potencial já um tanto esgotado das experiências contraculturais que vivenciou durante o exílio forçado na Inglaterra, Gilberto Gil reproduz a frase em "O sonho acabou", faixa de seu primeiro disco pós-exílio, LP Expresso 2222 (1972).
} 
de Andrade e Oswald de Andrade. Alguns aspectos históricos e sociológicos teriam alcançado certa universalidade nesse arco temporal. Dentre outros autores que se dedicaram ao assunto, Marcos Napolitano detectou na figura do artista-intelectual da época uma convergência de historicidades: rejeição do academicismo convencional e eurocêntrico, imperativo de participação na vida política e tentativa de "ida ao povo", fonte e destino da arte nacional moderna (NAPOLITANO, 2014, p. XVIII). E na leitura semelhante de Renato Ortiz e Marcelo Ridenti, ambos embasados na análise de Perry Anderson (1986) sobre o modernismo europeu, o "ciclo das vanguardas" na arte e na política brasileiras emergiu graças a coordenadas sócio-históricas específicas, sobretudo nosso processo ainda embrionário de revolução industrial - condição que teria gerado a crença compartilhada no potencial emancipador das inovações tecnológicas - e a proximidade imaginativa da revolução social (RIDENTI, 2010, p. 160-164; ORTIZ, 2006, p. 104-110).

Em livro clássico sobre as vanguardas históricas europeias do início do século XX, Peter Bürger compreende a vanguarda - palavra derivada do vocabulário militar, daí também sua íntima ligação com movimentos políticos - como fruto por excelência da sociedade burguesa, na qual a arte atinge uma determinada esfera de autonomização. Autocrítico por essência, o protesto da vanguarda estaria justamente voltado contra a instituição-arte como um todo. Seus alvos primordiais seriam o esteticismo modernista e a consequente cisão que o modernismo teria operado entre arte e vida cotidiana, ou, como prefere, entre arte e práxis vital (BÜRGER, 2008).

Termos antitéticos, portanto, segundo a Teoria da vanguarda de Peter Bürger, Modernismo e Vanguarda dividiram, ao contrário, uma linha tênue na experiência brasileira. Embora possuíssemos "um presente técnico ainda indeterminado e um futuro político ainda imprevisível" nos faltaria um passado clássico ou uma tradição artística, "referência obrigatória para os críticos do academicismo oficial", completamente formalizados e institucionalizados pelo Estado. Para Renato Ortiz, esse fenômeno “permitiu um 'livre trânsito', uma aproximação entre grupos inspirados pelas vanguardas artísticas, como os concretistas, e movimentos de música popular" como a bossa nova e o tropicalismo (ORTIZ, 2006, p. 104-105), este último normalmente considerado como o ponto de inflexão e de declive de nosso ciclo vanguardista ou modernista ${ }^{18}$.

Numa época em que se registravam avanços significativos nos meios técnicos de produção e de comunicação, além de uma alta intelectualização da música popular, foi para

\footnotetext{
18 Ver, por exemplo, Marcelo Ridenti (2002), Nicholas Brown (2007) e o dossiê "Vanguarda e pós-modernismo", coordenado por Celso Favaretto, Otília Arantes, Iná Camargo Costa e Walter Cezar Addeo (1983) na Arte em Revista, e, nesse dossiê, sobretudo o ensaio "Depois das vanguardas" de Otília Arantes (1983). Do tropicalismo musical, tema abordado sob os mais diversos ângulos por esses e outros inúmeros autores - como Schwarz (1978), Favaretto (2007), Callado (1997), Napolitano (2001), Dunn (2009), para citar alguns -, participaram Caetano Veloso, Gilberto Gil, Tom Zé, Gal Costa, Os Mutantes, Torquato Neto, José Carlos Capinan, Rogério Duprat, dentre outros nomes.
} 
a indústria cultural que os tropicalistas direcionaram a retomada da antropofagia oswaldiana e a interlocução com o concretismo, o neoconcretismo, a nova figuração e demais tendências vanguardistas. Dialogando com o "teatro da agressão", o Cinema Novo, a Jovem Guarda e com o legado da Bossa Nova, foram ainda responsáveis por dinamitar, através dos vestuários, dos happenings e da matéria da canção, o universo sonoro, valorativo e comportamental da contracultura. Tudo isso confrontou o autoritarismo militar e os nacionalismos à direita e à esquerda, bem como o imperativo de participação político-social característico, grosso modo, da MPB. Tensionando, assim, "alta e baixa cultura", o movimento teria efetuado uma crítica e autocrítica do estado da arte em que se encontrava a canção mediatizada no Brasil. Se, então, para Bürger, apenas a vanguarda conduz a arte à autocrítica, incentivando a superação de normas e padrões estilísticos e o reconhecimento de fases anteriores do seu desenvolvimento, esse teria sido, guardadas as devidas proporções conforme analisa José Roberto Zan, o papel do tropicalismo na canção popular brasileira (ZAN, 1996, p. 222-229).

Guardadas as devidas proporções já que a concepção histórica de vanguarda não admite (numa terminologia marxiana) o fetiche da mercadoria, pois seu protesto tem exatamente como alvo a instituição-arte na sociedade burguesa. Ou seja, vanguarda e indústria cultural seriam inconcebíveis. Nesse sentido, contudo, e mais coerente para se pensar o caso brasileiro, Andreas Huyssen argumenta, a partir de Walter Benjamin, sobre a existência de uma dialética oculta entre vanguarda e cultura de massa, sem, no entanto, confundi-las - raciocínio, aliás, também presente em Umberto Eco quando distingue "o experimental como questionamento do saber precedente" (experimentalismo como vanguarda) e o "experimental como preparado de laboratório para um produto industrial" (ECO, 2016, p. 236). Para Huyssen, nenhum outro fator determinou tanto a revolta da vanguarda e sua negação da tradição artística institucionalizada do que a tecnologia desenvolvida ao longo do século $X X$, utilizada para além de mero suporte e veículo de divulgação, mas como elemento intrínseco e estruturante da obra. Canalizada para a indústria cultural, a tecnologia transformou aquilo a que a vanguarda se propunha: a vida cotidiana (HUYSSEN, 1997, p. 22-40).

Por justamente assimilar o massivo e disponibilizar tecnologias e técnicas criativas (como a minimalista) para o usufruto da indústria cultural, talvez neovanguarda - oriunda do contexto europeu e estadunidense do pós-guerra - seja a expressão mais adequada tanto para o tropicalismo quanto para uma parcela da produção artística do pós-68. A discussão terminológica, porém, segue irresoluta, levando em conta que, no Brasil, cujo "ciclo vanguardista ou modernista" nunca se desatou da questão nacional e tampouco esteve apartado da indústria cultural - ainda incipiente até pelo menos o fim dos anos 1960 -, não houve "vanguardas históricas" para se falar em "neo" ou em "segundas vanguardas" (ver FREITAS, 2013, p. 36-40). Além disso, o tropicalismo teria sido um movimento que rompeu com a própria noção de movimento, pois, "ao contrário das vanguardas estéticas, que 
geralmente postulam a ruptura radical com a tradição, [...] ele adotou uma atitude incorporativa com relação a grande parte do repertório popular musical" (NAVES, 2004, p. 47-48), incluindo o repertório romântico pré-Bossa Nova de boleros e sambas-canções, posto de lado pela canção engajada ou de protesto.

Vanguarda ou não, a crítica ou a desconstrução tropicalista da canção - através do rock, do kitsch, da pop art e de arranjos inorgânicos repletos de citações e de colagens à la Dada - foram levadas adiante pela "geração 70" (NAVES, 2010, p. 95-107; FAVARETTO, 2016). Assumindo a liberdade estética e político-ideológica que o tropicalismo aguçou na canção brasileira, tal geração heterogênea de músicos, sob o Al-5 e a reestruturação da indústria cultural, também recorreu a outras fontes e desenvolveu novas possiblidades. Um de seus expoentes mais radicais, e por isso um tanto quanto isolado em sua empreitada, Walter Franco abriu brechas pouco prováveis, provocando certa fissura num circuito já bastante hostil às iniciativas artísticas experimentais ou com alguma pretensão vanguardista. Em seu primeiro LP e num festival da TV Globo - emissora que então conquistava e manteria a hegemonia dos meios de comunicação de massa -, o compositor apresentou tratamentos formais inusitados à canção concebida até aquele momento e agregou à música popular procedimentos eletroacústicos dentre outras técnicas e informações absorvidas do avantgarde da música erudita contemporânea. Referindo-se ao álbum Ou não, mas principalmente à estranha e não menos genial "Cabeça" de Walter Franco, para Augusto de Campos "nem mesmo os protagonistas da Tropicália tinham ido tão longe” (apud STESSUK, 2008, p. 1).

\section{Referências}

ARAÚJO, Olívio Tavares de. Sinal de vida - Walter Franco: "já tenho a cabeça, só faltam tronco e membros". Revista Veja, São Paulo, n. 212, p. 83-84, 27 set. 1972.

ANDERSON, Perry. Modernidade e revolução. Novos Estudos Cebrap, São Paulo, n. 14, p. 2-15, fev. 1986.

ARANTES, Otília. Depois das vanguardas. Arte em Revista (Dossiê Vanguarda e pós-modernismo), São Paulo, CEAC, USP, ano 5, n. 7, p. 4-24, ago. 1983.

BAHIANA, Ana Maria. Walter Franco, sem medo, como as crianças. In: Nada será como antes: MPB anos 70, 30 anos depois. Rio de Janeiro: Senac Rio, 2006, p. 273-277.

BORGES, Jorge Luís. O idioma analítico de John Wilkins. In: Outras inquisições. São Paulo: Companhia das Letras, 2007, p. 121-126.

BOZZETTI, Roberto. Uma tipologia da canção no imediato pós-tropicalismo. Letras, Santa Maria, n. 34, p. 133-146, jan./jun. 2007.

BOZZO JUNIOR, Carlos. Militares regeram festival de música da Globo em 72. Folha de S. Paulo Ilustrada, São Paulo, p. E3, 27 mai. 2000.

BROWN, Nicholas. Tropicália, pós-modernismo e a subsunção real do trabalho sob o capital. In: CEVASCO, Maria Elisa; OHATA, Milton (org.). Um crítico na periferia do capitalismo: reflexões sobre a obra de Roberto Schwarz. São Paulo: Companhia das Letras, 2007. p. 295-309.

BÜRGER, Peter. Teoria da vanguarda. São Paulo: Cosac Naify, 2008. 
CALLADO, Carlos. Tropicália: a história de uma revolução musical. 4.ed. São Paulo: Ed. 34, 1997. COHEN, Renato. Performance como linguagem. São Paulo: Perspectiva, 2002.

DIAS, Márcia Tosta. Os donos da voz: indústria fonográfica brasileira e mundialização da cultura. São Paulo: Boitempo, 2000.

DIETRICH, Peter. Araçá azul: uma análise semiótica. Dissertação (Mestrado em Semiótica e Linguística Geral). FFLCH, USP, São Paulo, 2003.

DINIZ, Sheyla Castro. "Se oriente, rapaz...": misticismo, dualidade e anomia na canção "Oriente" (Gilberto Gil. LP Expresso 2222, 1972). Música Popular em Revista, Campinas, ano 3, v. 2, p. 119 145, jan./jun. 2015.

DUNN, Christopher. Brutalidade jardim: a Tropicália e o surgimento da contracultura brasileira. São Paulo: Ed. UNESP, 2009.

DUNN, Christopher. Contracultura: alternative arts and social transformation in authoritarian Brazil. Chapel Hill: The University of North Carolina Press, 2016.

DUPRAT, Rogério; MEDAGLIA, Júlio; COZZELLA, Damiano; MENDES, Gilberto, OLIVEIRA, Willy Correia de; et alii. Manifesto da nova música brasileira. Invenção, Revista de arte de vanguarda, ano 2, n. 3, jun. 1963. Disponível em: https://www.latinoamerica-musica.net/historia/manifestos/3-po.html. Acesso em: 10 fev. 2021.

ECO, Umberto. Experimentalismo e vanguarda. In: A definição da arte. Tradução de Eliana Aguiar. Rio de Janeiro/São Paulo: Record, 2016, p. 220-239.

FAVARETTO, Celso; ARANTES, Otília; COSTA, Iná Camargo; ADDEO, Walter Cezar (coord.). Dossiê Vanguarda e pós-modernismo. Arte em Revista, Centro de Estudos de Arte Contemporânea (CEAC), USP, São Paulo, ano 5, n. 7, ago. 1983.

FAVARETTO, Celso. Tropicália, alegoria, alegria. 4.ed. Cotia: Ateliê, 2007.

FAVARETTO, Celso. O Tropicalismo e a crítica da canção. Revista USP, São Paulo, n. 111, p. 117-124, out./dez. 2016.

FAVARETTO, Celso. A contracultura, entre a curtição e o experimental. São Paulo: N-1, 2019.

FOUCAULT, Michel. As palavras e as coisas: uma arqueologia das Ciências Humanas. Tradução de Salma Tannus Muchail. 8.ed. São Paulo: Martins Fontes, 1999.

FRANCO, Walter. Depoimento de Walter Franco concedido a Sheyla Diniz por e-mail em 19 nov. 2016.

FREIRE, Roberto. Eu é um outro. Salvador: Maianga, 2002.

FREITAS, Artur. Arte de guerrilha: vanguarda e conceitualismo no Brasil. São Paulo: EDUSP, 2013.

GAVIN, Charles. Entrevista de Walter Franco. O som do vinil: memória da música brasileira, 2014. Disponível em: http://osomdovinil.org/walterfranco/. Acesso em: 10 mar. 2015.

HUNGRIA, Júlio. Cada cabeça, cada sentença. O Pasquim, Rio de Janeiro, n. 170, p. 17, 2 a 7 out. 1972.

HUYSSEN, Andreas. A dialética oculta: vanguarda - tecnologia - cultura de massa. In: Memórias do modernismo. Tradução de Patrícia Farias. Rio de Janeiro: Ed. UFRJ, 1997. p. 22-40.

MEDAGLIA, Júlio. Crise da MPB. Jornal do Brasil, Caderno B, Rio de Janeiro, p. 5, 11 abr. 1972.

MELLO, Zuza Homem de. A era dos festivais: uma parábola. 3.ed. São Paulo: Ed. 34, 2003.

MIDANI, André. Entrevista com o cara que decide o que você vai ouvir. O Pasquim, Rio de Janeiro, n. 242, p. 8-12, 19 a 25 fev. 1974.

MORELLI, Rita. Indústria fonográfica: um estudo antropológico. 2.ed. Campinas: Ed. Unicamp, 2009.

MUGNAINI JR, Ayrton. Ou não? Sim! In: ALBUQUERQUE, Célio (org.). 1973: o ano que reinventou a MPB. Rio de Janeiro: Sonora, 2013. p. 393-401. 
MÚSICA BRASILEIRA em 72: louka retrospectiva. Rolling Stone, Rio de Janeiro, n. 36, p. 4, 5 jan. 1973.

NAPOLITANO, Marcos. A república das bananas: o tropicalismo no panorama da MPB. In: Seguindo a canção: engajamento político e indústria cultural na MPB (1959-1969). São Paulo:

Annablume/Fapesp, 2001, p. 231-286.

NAPOLITANO, Marcos. Arte e política no Brasil: história e historiografia. In: EGG, André; FREITAS, Artur; KAMINSKI, Rosane (org.). Arte e política no Brasil: modernidades. São Paulo: Perspectiva, 2014, p. XV-XLVI.

NAVES, Santuza Cambraia. Da Bossa Nova à Tropicália. Rio de Janeiro: Jorge Zahar, 2004.

NAVES, Santuza Cambraia. A desconstrução tropicalista da canção. In: Canção popular no Brasil: a canção crítica. Rio de Janeiro: Civilização Brasileira, 2010. p. 95-107.

NUZZI, Vitor. Geraldo Vandré: uma canção interrompida. Rio de Janeiro: Kuarup Produções, 2015.

ORTIZ, Renato. A moderna tradição brasileira: cultura brasileira e indústria cultural. São Paulo: Brasiliense, 2006.

ORTIZ, Renato. Cultura brasileira e identidade nacional. São Paulo: Brasilense, 2006b.

RIDENTI, Marcelo. Ensaio geral de socialização da cultura: o epílogo tropicalista. In: CARNEIRO, Maria Luzia Tucci (org.). Minorias silenciadas: história da censura no Brasil. São Paulo:

Edusp/Imprensa Oficial do Estado/FAPESP, 2002. p. 377-401.

RIDENTI, Marcelo. Do ciclo das vanguardas ao ciclo das bases: sinais das ruas. In: Brasilidade revolucionária: um século de cultura e política. São Paulo: Ed. UNESP, 2010. p. 160-164.

SCHWARZ, Roberto. Cultura e política, 1964-69. In: O pai de família e outros estudos. Rio de Janeiro: Paz e Terra, 1978. p. 61-92.

SCOVILLE, Eduardo Henrique Martins Lopez de. Na barriga da baleia: a rede Globo de televisão e a música popular brasileira na primeira metade da década de 1970. Tese (Doutorado em História). Universidade Federal do Paraná, Curitiba, 2008.

STESSUK, Sílvio. O silêncio em espirais: Walter Franco. Anais do XI Congresso Internacional da ABRALIC: tessituras, interações, convergências, São Paulo, USP, p. 1-10, 13 a 17 jul. 2008.

VARGAS, Herom. A canção experimental de Walter Franco. Comunicação \& Sociedade, ano 32, n. 54, p. 191-210, jul./dez. 2010.

VASCONCELLOS, Gilberto. Música popular: de olho na fresta. Rio de Janeiro: Graal, 1977.

VENTURA, Zuenir. O vazio cultural. In: GASPARI, Elio; HOLLANDA, Heloísa Buarque de; VENTURA, Zuenir. Cultura em trânsito: da repressão à abertura. Rio de Janeiro: Aeroplano, 2000. p. 40-51.

ZAN, José Roberto. Do fundo do quintal à vanguarda: contribuição para uma história social da música popular brasileira. Tese (Doutorado em Sociologia). IFCH, Unicamp, Campinas, 1996.

\section{Fontes discográficas}

CAETANO VELOSO. Araçá azul. Phonogram, Brasil, 1973. LP.

CAETANO VELOSO, GILBERTO GIL, GAL COSTA, TOM ZÉ, MUTANTES, JOSÉ CARLOS CAPINAN, TORQUATO NETO, ROGÉRIO DUPRAT, et al. Tropicália ou Panis et circencis. Philips/Phonogram, Brasil, 1968. LP.

CHICO BUARQUE. Sinal fechado. Phonogram, Brasil, 1974. LP.

GILBERTO GIL. Gilberto Gil. Phonogram, Brasil, 1969. LP.

GILBERTO GIL. Expresso 2222. Phonogram, Brasil, 1972. LP. 
JOHN LENNON; YOKO ONO. John Lennon/Plastic Ono Band. EMI, Inglaterra, 1971. LP.

MARCUS VINICIUS. Dédalus. Continental, Brasil, 1974. LP.

RAUL SEIXAS. Krig-Há Bandolo. Phonogram, Brasil, 1973. LP.

SECOS \& MOLHADOS. Secos \& Molhados. Continental, Brasil, 1973. LP.

VII FIC. As 12 finalistas do VII Festival da Canção Popular. Som Livre, Brasil, 1972. LP.

THE BEATLES. The Beatles (Álbum branco). Apple Records, Inglaterra, 1968. LP.

THE BEATLES. Rubber Soul. Parlophone, Inglaterra, 1965. LP.

THE BEATLES. Sgt. Pepper's Lonely Hearts Club Band. Parlophone, Inglaterra, 1967. LP.

THE BEATLES. Abbey Road. Apple Records, Inglaterra, 1969. LP.

THE BEATLES. Revolver. Parlophone, Inglaterra, 1966. LP.

TOM ZÉ. Todos os olhos. Continental, Brasil, 1973. LP.

WALTER FRANCO. Tema do hospital. Philips/Phonogram, Brasil, 1971. Compacto simples.

WALTER FRANCO. Ou não. Continental, Brasil, 1973. LP.

WALTER FRANCO. Revolver. Continental, Brasil, 1975. LP.

WALTER FRANCO. Vela aberta. Epic/CBS, Brasil, 1979. LP.

\section{Fontes audiovisuais}

BECHARA, Bel; SERPA, Sandro. Walter Franco Muito tudo. Mega/Zootrópio, Brasil, 2000, 25 min., Documentário, DVD.

FRANCO, Walter; MARIA, Sílvia. Tema do hospital (Walter Franco). Vídeo de 2 minutos e 28 segundos postado por Abertura de Novelas, s./d. Abertura da novela Hospital, direção de Benjamin Cattan e Wálter Avancini, 115 capítulos, TV Tupi, Brasil, 1971. Disponível em:

https://www.youtube.com/watch?v=BPs8O3HigoA. Acesso em: 10 fev. 2021.

MACALÉ, Jards; OS BRAZÕES. Gothan City (Jards Macalé; José Carlos Capinan). Áudio de 7 minutos e 20 segundos postado por Pedro Herzog em 2013. Apresentação de Jards Macalé e Os Brazões no IV Festival Internacional da Canção da TV Globo, Brasil, 1969. Disponível em: https://www.youtube.com/watch?v=epz1isKVpTQ. Acesso em: 04 fev. 2021.

MACHADO, Marcelo. Tropicália. Bossa Nova Films/Imagem Filmes, Brasil, 2012, 87 min., Documentário, DVD.

Fontes iconográficas

Figura 1 - Walter Franco (anos 1970). INSTITUTO MOREIRA SALES, Rádio Batuta, 2019. Disponível em: https://radiobatuta.com.br/selecao/walter-franco/. Acesso em: 10 fev. 2021.

Figura 2 - Roberto Freire sendo arrastado do palco do VII FIC. MELLO, Zuza Homem de. A era dos festivais: uma parábola. 3. ㄹ ed. São Paulo: Ed. 34, 2003, p 429.

Figura 3 - O FIC e sua maravilhosa plateia! HENFIL. O Pasquim, Rio de Janeiro, n. 170, p. 16, 2 a 7 out. 1972.

Figura 4 - Capa/contracapa do LP de Walter Franco Ou não. Continental, 1973.

Figura 5 - Capa do LP de Walter Franco Revolver. Continental, 1975. 